\title{
Grizzly Bear Mortality and Studies in Montana
}

\author{
KENNETH R. GREER \\ Montona Fish and Game Department, Bozeman, Montana
}

\section{SUMMARY}

The former and present status of grizzly bear (Ursus arctos) mortality in Montana is reviewed. Laws revised in 1967 provide an accurate documentation of the grizzly harvest. Commission regulations permit recovery of specific samples from grizzlies, harvested by hunters, for scientific purposes. Grizzly heads are obtained and examined before being returned to the hunter. Some illegal and marauding grizzly bears are taken each year in Montana. These complete specimens are handled jointly with the Veterinary Research Laboratory. The known man-caused mortality (including hunters) of grizzly bears in Montana during 1967, 1968 and 1969 was 41,28 , and 48, respectively. Hunters harvested 24,12 and 33 grizzlies for the respective years of 1967 , 1968 and 1969 . Female grizzlies represented 39 percent of the hunter harvest in 1969,25 percent in 1968 and 35 percent in 1967. Internal parasites recovered from grizzly carcasses included: porkworm larvae (Trichinella spiralis), large roundworms (Baylisascaris lransfuga), tapeworms (Taenia sp. and Diphyllobothrium sp.) and hookworms (Unicaria sp.). Trichinella was the most frequent parasite and occurred in 79 percent of the grizzlies in 1968 and 67 percent in 1969. Routine testing for brucellosis and leptospirosis was negative. Analysis of fat samples from 10 grizzly bears revealed only one had a pesticide residue and that was a trace of $\mathrm{DDE}$ and $0.06 \mathrm{ppm}$ of heptachlor epoxide. The regular appearance of grizzlies in the West Yellowstone dump is a potential danger to humans.

\section{INTRODUCTKN}

Among the western states, Montana has the largest population of grizzly bears (Ursus arctos). In the past 30 years or more, Montana has had liberal annual hunting seasons for black (Ursus americanus) and grizzly bears. A resident or non-resident with a valid big game license was permitted to kill either one black bear or grizzly bear per license. Black bear seasons commence in the spring (March 15) and continue uninterrupted into the summer and through the hunting seasons. Grizzly bear seasons were confined to the general big game hunting seasons.

An unknown number of bears were killed each year up till 1947, when Department personnel established an estimate of the annual harvest of grizzly bears in Montana. From 1947 through 1966 the estimated annual harvest ranged from 20 to 60 grizzlies, except for 2 years in the early 50's (Table 1). The results of a sharply reduced estimate of 14 grizzlies harvested in 1950 and 10 in 1952 from the previous estimates of 50-55 grizzlies warranted a review of the inventory. Surveys conducted in 1953 and 1954 to corroborate the annual 
TABLE 1. ESTIMATED TOTAL HARVEST OF GRIZZLY BEARS

\begin{tabular}{llllllll} 
Year & Number & Year & Number & Year & Number & Year & Number \\
\hline 1947 & 55 & 1952 & 10 & 1957 & 20 & 1962 & 40 \\
1948 & 55 & 1953 & 40 & 1958 & 40 & 1963 & 35 \\
1949 & 50 & 1954 & 35 & 1959 & 60 & 1964 & 40 \\
1950 & 14 & 1955 & 35 & 1960 & 30 & 1965 & 30 \\
1951 & 25 & 1956 & 20 & 1961 & 60 & 1966 & 45 \\
\hline
\end{tabular}

estimates revealed that 33 grizzlies were harvested in 1953 (Stockstad 1954) ard 39 in 1954 (Marshall 1955). Each survey. noted that additional grizzlies may have been killed by trappers, ranchers, sheepherders or cattlemen. The estimated annual harvest averaged 40 grizzly bears during 1961-1966.

Since 1967 the annual grizzly bear harvest in Montana has been determined from special hunting licenses along with a program to recover all other grizzlies killed during the year. This report describes the recent hunter harvests and other known instances of man-caused mortality in the grizzly bear populations of Montana.

\section{METHODS}

\section{Laws, Regulations and Hunting Seasons}

Legislative assistance was necessary to establish a firm basis for determining the status for hunter harvests of grizzly bears in Montana. The State Legislature enacted licenses for grizzly bears which were effective for the 1967 season. The two licenses are specific for the hunters and for the harvest. A special $\$ 1.00$ grizzly bear license is required for the resident and a similar license for the non-resident is $\$ 25.00$. When a special grizzly bear licensee kills a grizzly bear he must file an application for a Grizzly Bear Trophy License with a fee of $\$ 25.00$, within ten (10) days after date of kill. A specially designed Trophy License, suitable for framing, is returned to the owner, with a personal letter of recognition from the Department Director.

Grizzly bear hunting licenses $(\$ 1.00)$ are issued by several license agents in the State. During 1967-1969 licenses were available throughout the respective hunting year. In 1970, the sale of grizzly bear hunting licenses was prohibited after the opening date of the first general big game season (September 14, 1970).

Black and grizzly bears were classified as trophy animals and the Law required that only the hide or the head must be recovered from a bear after it was killed. Although this law was in effect during 1967 and 1968, some grizzly bear hunters cooperated with the Department's request to recover the heads from their grizzly bears. The 1969 Legislature revised the laws on grizzly bears by requiring grizzly bear hunters to bring out at least the hide and the 
head from these bears. Commission policies established mandatory procedures for identifying hides and heads with numbered, metal seal tags, and to relinquish grizzly bear heads for scientific purposes of examination before being returned to the owner.

Open season for grizzly bears coincides with deer or elk seasons in all districts except in areas specified as closed. In 1969 the general big game season extended from October 19 to November 30, except for a few areas which opended on September 15, 20, or 27. There is no spring hunting season for grizzly bears. The limit is one grizzly bear per person per license year. Cub grizzly bears or female grizzlies with cubs at side may not be taken.

\section{Determining Man-caused Mortality}

Special grizzly bear hunting licenses provide a reliable indication of hunter intensities and accurate records of the grizzly bear harvests in Montana. Throughout the year some grizzlies are killed illegally, by accidents or dispatched as marauders. These categories (Table 3 ) appear to provide a comprehensive coverage of man-caused mortality but occasionally for some reason or circumstance a few instances of grizzly bear mortality may not become known in any year. With the assistance and cooperation of Department, U.S. Fish and Wildlife Service, Park Service and other personnel, an extensive survey can be established for the annual (April through December) mortality. This information will be necessary for management programs of Montana grizzly bear populations.

\section{FINDINGS}

\section{Identification of Grizzly Bears and Black Bears}

The establishment of grizzly bear trophy licenses required an accurate identification of the bears by Department personnel. Some of the black bears in Montana are quite variable in size and coloration (Jonkel 1967) and have been mistaken for a grizzly bear. In previous years when the head was not required to accompany the pelt, an accurate identification for a grizzly was difficult for some pelts. With the present regulation that a grizzly bear head must be available, an examination of the last upper molar will reveal the species. In the event that it may be difficult to examine these teeth, another reliable feature for identification are the feet.

Some features of the feet are distinguishable between the black and grizzly bears (Greer \& Craig 1970). The front claws of grizzlies may be of great length but in several grizzlies these claws are worn down to a length comparable to black bears. However, claw profiles differ between the species. On the front and rear feet, dense hair is present between the foot pad and toe pads of black bears compared to sparse hair in grizzlies.

Skin webbing is at the base of front and rear toe pads in black bears while webbing is about half way up the toe pads in grizzly bears. The base of toe pads are widely separated in the front and rear feet of black bears. Toe pad bases are close together in the front feet of grizzlies; however, some of the toe pads in rear feet of grizzlies are usually fused.

The instep areas of rear feet in black bears frequently have an indented wedge of hair present in the pad but this feature does not appear in the rear feet of grizzly bears. 


\section{Hunting Interest and Success}

It appears that very few licensees are dedicated and determine for a grizzly trophy hunt. A few hunters, guides or outfitters may frequently locate and observe grizzlies. However, most of the licenses are held by hunters for the authority to kill a grizzly if the opportunity arises while hunting for another species.

Resident grizzly bear hunting licenses increased from 1, 022 in 1967 to 1, 474 in 1969. The 137 to 164 licenses issued to non-residents during 1967-69 represented 10 to 12 percent of the total (Table 2).

TABLE 2. GRIZZLY BEAR LICENSES ISSUED IN MONTANA

\begin{tabular}{|c|c|c|c|c|c|c|}
\hline & \multicolumn{3}{|c|}{ GRIZZLY LICENSE } & \multicolumn{3}{|c|}{ TROPHY LICENSE } \\
\hline & 1967 & 1968 & 1969 & 1967 & 1968 & 1969 \\
\hline Resident & 1,022 & 1,149 & 1,474 & 21 & 9 & 30 \\
\hline Non-resident & 143 & 137 & 164 & 3 & 3 & 3 \\
\hline Total & 1,165 & 1,286 & 1,638 & 24 & 12 & 33 \\
\hline
\end{tabular}

Hunting success is expectantly low and ranges from less than 1 to 2 percent. While non-residents have reportedly taken a few grizzlies in each of the 3 years, the residents eminently harvested 75 to 91 percent of the grizzlies during 1967,1968 , and 1969.

\section{Annual Mortality}

Hunters accounted for 24 of 41,12 of 28 and 33 of 48 of the grizzly bears harvested in Montana during 1967, 1968, and 1969, respectively. Thus from 15 to 17 additional grizzlies were removed from the Montana populations in the same years. These grizzlies were dispatched as marauders, illegals, or by natives of Indian reservations (Table 3 ).

\section{Distribution}

The Montana grizzly bear populations are closely bordered on the north by the Glacier National Park population but separated to some extent on the south from the Yellowstone National Park population. Grizzly bears from these protected Park populations also disperse into Montana. Within the two adjacent Park areas, 2 to 4 grizzlies from Glacier and 6 to 12 from Yellowstone were removed from the Park populations during the respective years of 1967, 1968 and 1969.

The distribution of the 1969 grizzly bear harvest is indicated in Figure 1. About 60 percent ( 20 of 33 ) of the grizzly harvest by hunters in 1969 was in the three areas surrounding the Sun River Game Preserve. The same areas accounted for 38 percent of the hunter harvest in 1967 and 66 percent in 1968 . 


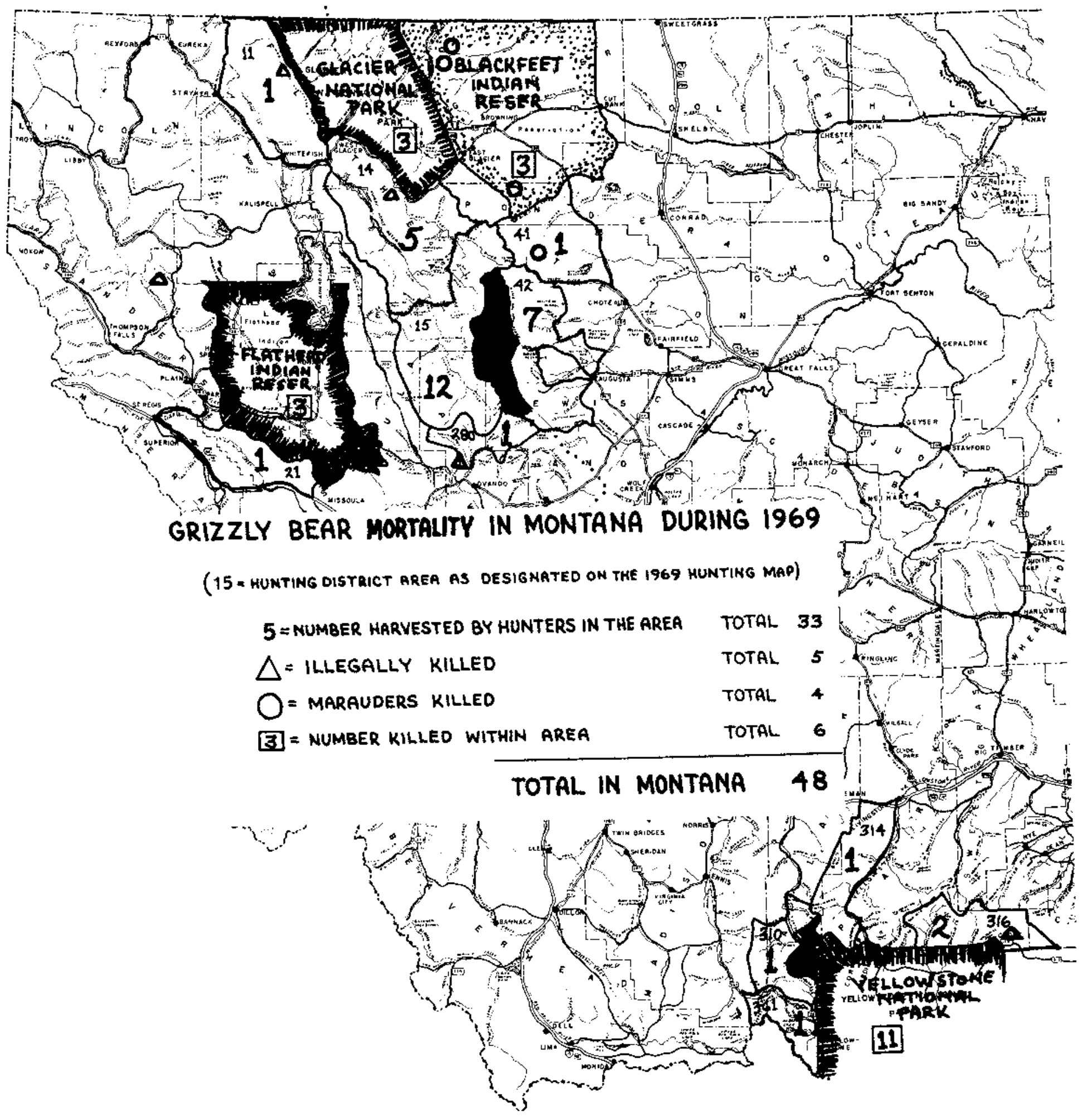

Fig. 1. Distribution of 1969 grizzly bear mortality in Montana. 



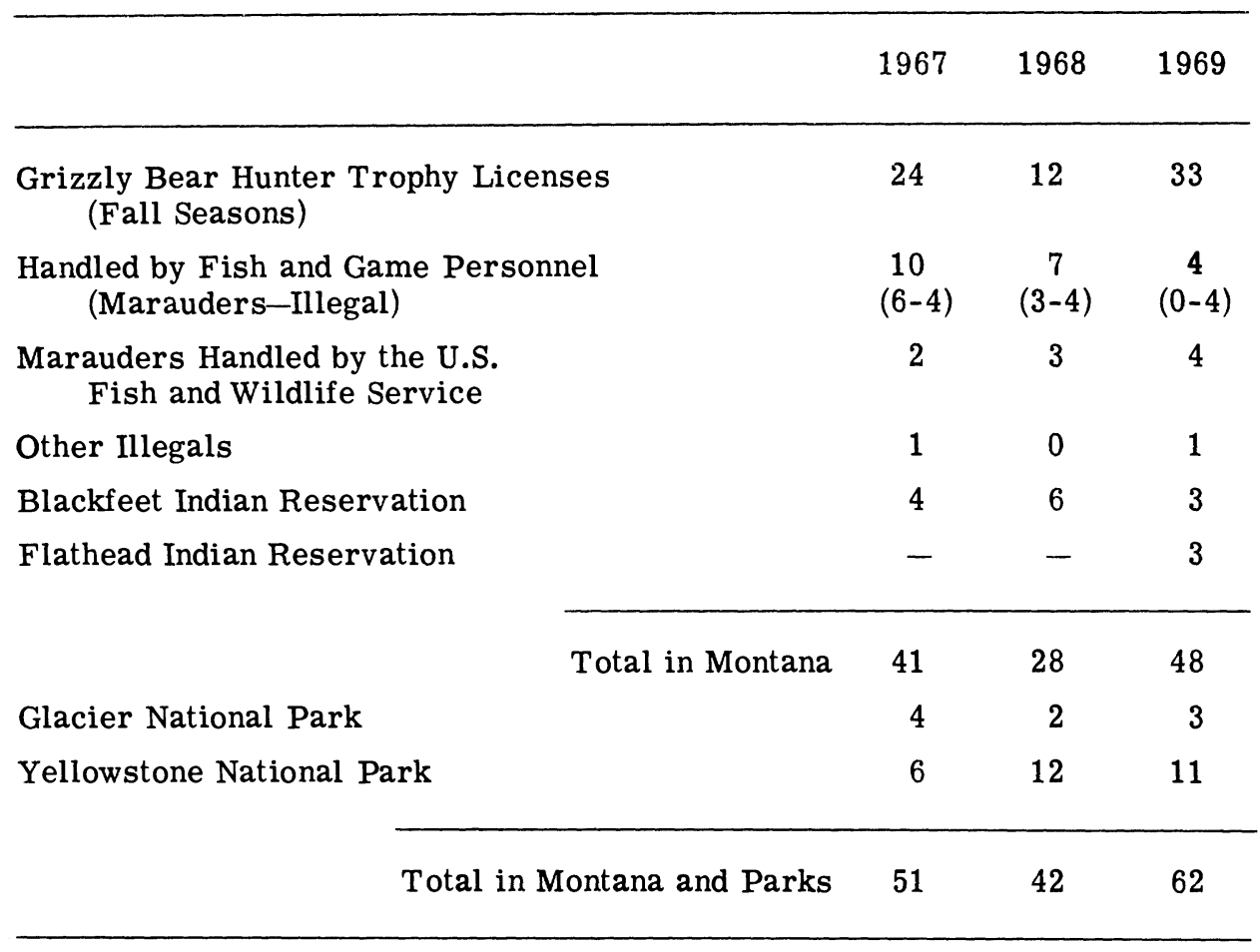

In 1969 hunters harvested five grizzlies in the areas immediately adjacent to Yellowstone National Park and two to three were taken in the two previous years (Table 4).

Weather conditions and food sources are quite variable each year and are important factors which influence grizzly distribution and their availability to hunters and people. The annual harvests are therefore expected to fluctuate between known limits and an alarmist action is not usually necessary until extreme harvests are consistent. The documented annual harvest has averaged 39 (28-48) bears for 1967-1969. This average is in complete accordance with the estimated 20 to 60 (average 40 ) grizzly harvest each year during 1957-1966.

\section{Sex Mortality}

Information from the Trophy License application included date of kill, location, sex, claw lengths and foot pad measurements. Skull sizes overlap between sexes and, except for the larger males, are of little value for verification of sex. Hides are presented in a rolled, salted, frozen or packed condition and are inconvenient and difficult to examine. Also, sex determination from pelts is not dependable as the prominent features are always trimmed off. Therefore, the designation of sex is dependent upon the hunter's observation and report on the Trophy License. 
TABLE 4. ANNUAL HARVEST OF GRIZZLY BEARS IN HUNTING AREAS OF MONTANA

\begin{tabular}{|c|c|c|c|}
\hline \multirow[b]{2}{*}{ Hunting Area } & \multicolumn{3}{|c|}{ NUMBER TAKEN } \\
\hline & 1967 & 1968 & 1969 \\
\hline $\begin{array}{r}11 \\
14 \\
15 \\
101 \\
131\end{array}$ & $\begin{array}{l}2 \\
3 \\
7 \\
1 \\
2\end{array}$ & $\begin{array}{l}- \\
\frac{-}{7} \\
\frac{1}{1}\end{array}$ & $\begin{array}{r}1 \\
5 \\
12 \\
- \\
-\end{array}$ \\
\hline $\begin{array}{r}21 \\
28 \\
280 \\
281\end{array}$ & $\begin{array}{l}- \\
1 \\
3 \\
1\end{array}$ & $\begin{array}{l}- \\
- \\
-\end{array}$ & $\begin{array}{l}\frac{1}{1} \\
-\end{array}$ \\
\hline $\begin{array}{l}310 \\
314 \\
316 \\
361\end{array}$ & $\begin{array}{l}- \\
\frac{-}{2} \\
-\end{array}$ & $\begin{array}{l}- \\
- \\
-\end{array}$ & $\begin{array}{l}1 \\
1 \\
2 \\
1\end{array}$ \\
\hline $\begin{array}{l}41 \\
42\end{array}$ & $\overline{2}$ & $\overline{1}$ & $\begin{array}{l}1 \\
7\end{array}$ \\
\hline Total & 24 & 12 & 33 \\
\hline
\end{tabular}

The reproductive performance of female grizzly bears is that of slow maturity to an ir regular age for producing a first litter and non-rhythmic recurring pregnancies of some individuals. It has been reported that female grizzlies do not usually conceive a first iitter until at least $41 / 2$ years of age and some females did not have the first litter until $5,6,7,8$, or 9 years of age. The time between succesive litters of some individuals can be 2 or 3 years (Craighead et al.1968). Females of productive age are therefore, a critical segment in grizzly bear populations.

As in the two previous years, male grizzly bears were predominantly har vested by the hunters. The female grizzlies represented 39 percent of the hunter harvest in 1969, 25 percent in 1968, and 35 percent in 1967. At least 15 additional grizzlies were killed during 1969 and the sex was known for only 8 of these; 7 females and 1 male. A total of 48 grizzlies (21 males, 20 females, 7 unknown) is known to have been removed from the Montana populations in 1969. 


\section{Age Mortality}

The third lower molar (Munday \& Fuller 1964) and the fourth lower premolar (Craighead et al.1970) of grizzly bears are criteria for age determinations. An obliteration of skull sutures in grizzlies is obviously correlated with age and sequence of fusions may be similar to that of the black bear (Marks \& Erickson 1966). Therefore, every effort is being made to obtain and examine the head of each grizzly mortality.

Skulls are cleaned, examined and photographed. Some teeth are extracted for root segments and the remaining portions are replaced. Grizzly skulls from hunting trophies are returned to the respective owners.

Recovery of grizzly skulls from the annual mortality has increased from 35 to 82 percent in the past 3 years (Table 5). A new regulation requires the hunter to recover the grizzly head and it is expected that all of these and more than 70 percent of the skulls from the other grizzly mortality will be available for examination.

Only 17 skulls were available from the 20 females killed in 1969 and ages were tentatively classified as: 1 cub, 5 sub-adults and 11 adults.

\section{TABLE 5. ANNUAL GRIZZLY MORTALITY AND SKULLS AVAILABLE FOR EXAMINATION}

\begin{tabular}{lrrr}
\hline Year & 1967 & 1968 & 1969 \\
\hline Hunter-Harvest- & 24 & 12 & 33 \\
$\quad$ Skulls & 0 & 7 & 27 \\
Other-Mortality- & 17 & 16 & 15 \\
$\quad$ Skulls & 8 & 8 & 10 \\
Parks-Mortality- & 10 & 14 & 14 \\
$\quad$ Skulls & 10 & 13 & 14 \\
Total-Mortality- & 51 & 42 & 62 \\
$\quad$ Skulls & 18 & 28 & 51 \\
Percent-Skulls & 35 & 67 & 82 \\
\end{tabular}

\section{Hunter Replies}

The grizzly has foraging characteristics which include visiting game kills, offal piles, camps or refuse areas. On occasions bears are observed while traveling on trails, in the timber, in open meadows or even in a resting area. Usually the grizzly tends to be elusive and rather difficult to locate and observe but at times they will command and defend a food supply. Along with these comments, several questions were asked of the 33 hunters taking a grizzly during the 1969 season. 29 responded.

Grizzlies were located by hunters under various circumstances. About half of the grizzlies killed were accidentally encountered in the trail, in a meadow or in the brush or timber while the hunter was pursuing elk. Five were found 
on an offal pile or on a deer or elk kill; two came into camp; one was in the yard of a home; and six were subjectively hunted.

When shooting their bears, nine hunters reported that at least one other bear was in the vicinity. Only six hunters stalked closer after sighting the bear. All grizzlies were killed at a range of under 200 yards; 12 ranged between 100 and 200 yards while the rest were 75 yards or less. Twenty of the bears were killed with only one shot. Nine hunters killed a big game animal before killing a grizzly. About 12 hunted more than 1 day for a grizzly, 12 sighted more than one grizzly and only one reported to have passed up a bear before shooting the one he did.

Of the 29 respondees 8 were guides or outfitters, 6 were with guides, 14 hunted on their own and 1 did not answer this question.

\section{Other Harvest}

Wherever grizzlies occur there is an occasional association with humans or their personal property. Under some circumstances, grizzlies are considered a hazard to the public and when trapping and transplanting is not feasible the animal is dispatched by shooting or lethal injection of drugs. These specimens are usually transferred to the Bozeman laboratories.

A program is continuing for obtaining, examining and processing grizzly bears taken during the year. Agencies cooperating with the Montana Fish and Game Department Wildlife Laboratory include: Veterinary Research Laboratory, Montana Livestock Sanitary Board, Montana Wildlife Cooperative Research Unit, U.S. Fish and Wildlife Service Predator Control, Glacier National Park and Yellowstone National Park (Table 6).

\section{Parasite Studies}

The grizzly heads from hunter kills or complete carcasses of 57 bears ( 37 grizzlies and 20 blacks) were examined for parasites in 1969 . When the entire carcass was available, a complete necropsy was performed, including a search for both external and internal parasites. In instances where only the head was submitted, the tongue and masseter were examined for evidence of porkworm larvae (Trichinella spiralis). Examinations were conducted by the Veterinary Research Laboratory.

Trichinella was the most frequent parasite, occurring in 67 percent of the grizzlies. The tissues sampled for larvae were the tongue, masseter and, when available, the diaphragm and a portion of the thigh muscle. The heaviest infections were found in the tongue and masseter. In two grizzly bears, concentrations of larvae were present in the muscles which approached or surpassed lethal levels (over 100 larvae per gram) for man. In 1968, larval concentrations ranged from 0.3 to 142.7 larvae per gram in 79 percent (11 of 14) of the grizzly tongues examined. Larvae of Trichinella were not found in any of the black bears during 1969; however, this parasite was present in one of the two black bears examined in 1968 .

The most common gastro-intestinal parasite was the large roundworm (Baylisascaris transfuga). It occurred in 85 percent (11 of 13) of the grizzlies and 71 percent (five of seven) of the black bears as light infections with less than ten roundworms per bear. In 1968, four of five grizzlies and one of two blacks contained this roundworm.

Two types of tapeworms were recovered; a Taenia species in four grizzlies and one black, and a species of Diphyllobothrium in four grizzlies. 


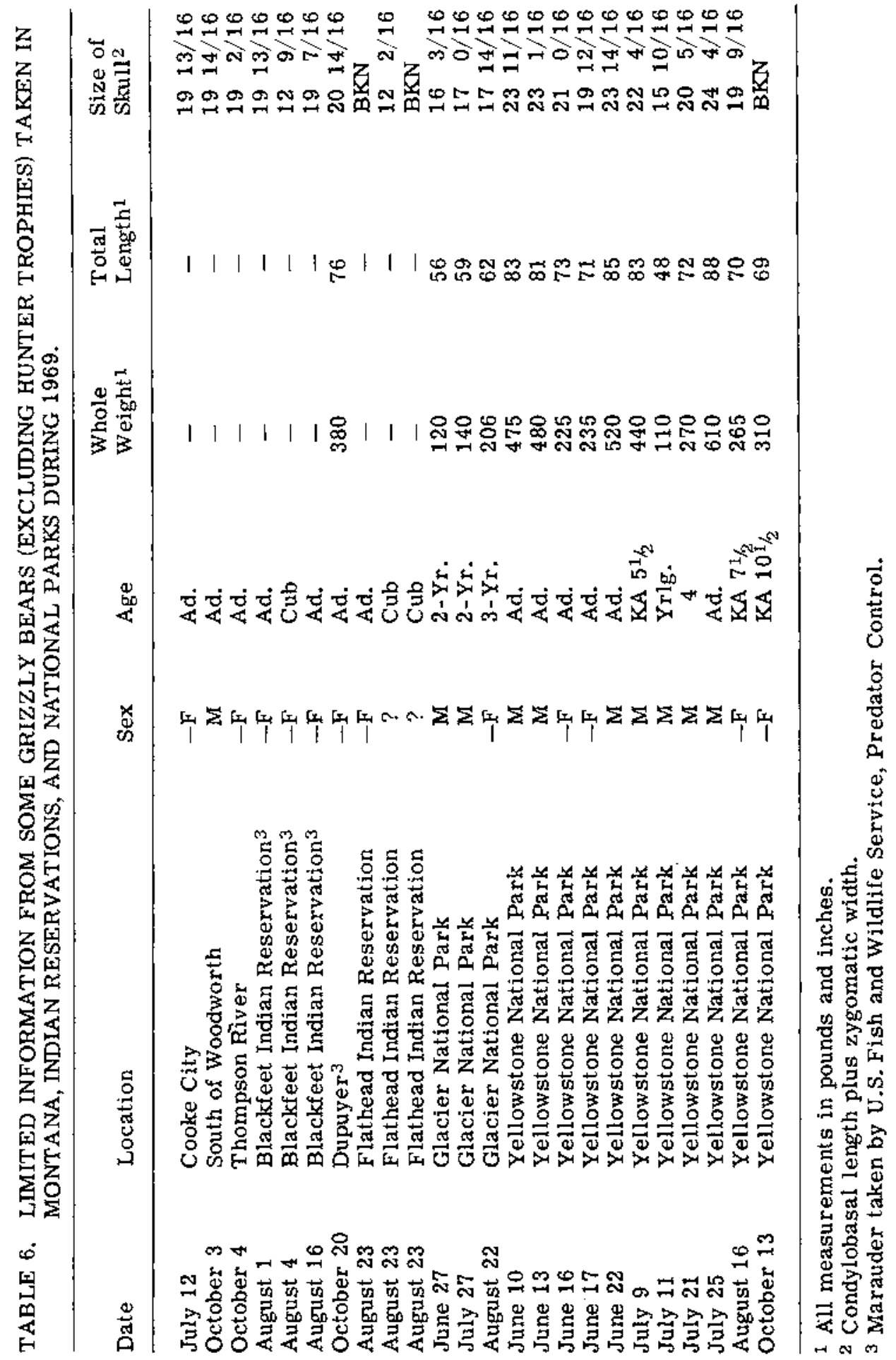


An undetermined species of hookworm (Uncinaria sp.) was found in the small intestine of two young grizzlies from Glacier National Park. This hookworm was present in one black bear during 1968.

Since some bear carcasses were not available until several hours after death, examinations for external parasites were limited to the more recently expired animals, about half of the bears submitted. Woodticks (Dermacentor andersoni) were noted on only one black bear.

\section{Diseases}

Blood samples from three grizzly bears were negative for brucellosis and leptospirosis.

\section{Fat Samples}

Samples of fat are usually obtained from the kidney area of grizzly bears. Of the ten samples analyzed for pesticide residue, only one revealed a trace of DDE with $0.06 \mathrm{ppm}$ of heptachlor epoxide.

\section{Undesirable Distribution}

A few grizzly bears occasionally forage in the West Glacier and Polson garbage dumps but the garbage dump at West Yellowstone is continually visited by several grizzlies. The West Yellowstone dump is located on Forest Service land and is about 2 miles north of the town limits of West Yellowstone, a halfmile south of Baker Hole campground and about 100 yards east of U.S. Highway 191.

The forest Service has issued a 'Land Use Permit' to the town of West Yellowstone for the purpose of garbage disposal. In turn, the Town Council of West Yellowstone issued a permit to an individual agent to service the town by removing local refuse and depositing it in the area designated.

In 1969 , as in previous years, this dump was operated in an open manner and potentially hazardous conditions prevailed. The service road was accessible to anyone; dumping was on an intermittent basis; garbage was not leveled or covered; the public freely visited the area to observe the bears; bears were exclusively grizzlies; some people were dangerously exposed while in the midst of grizzly bears; at least 17 individual grizzly bears were foraging the area throughout the summer, and up to 15 grizzlies visited the area during hours of darkness in one evening.

In 1969 , huckleberry crops were locally well below average, the fall season had extended mild temperatures, winter snowfall was late, and a reduced volume of garbage was intermittently deposited at the dump. These factors probably influenced the frequent appearances of several grizzlies, a minimum of eight during some nights, searching garbage cans in the town limits of West Yellowstone as early as mid-September and continuing through October, 1969.

Meetings of responsible and concerned persons resolved some corrective measures which were implemented before the summer of 1970 . The improvements included: a locked gate on the access road; regular dumping to maintain continued interest and use by the bears; spread and cover the garbage daily; and place signs at the gate warning unauthorized persons not be in the area during darkness.

At least 25 individual grizzlies were known to visit the West Yellowstone dump in 1970. From 20 to 22 grizzlies were observed in the dump one or two times 
a week during July, August and September. In the last few days of September, 17 grizzlies appeared and in early October, 6 were present (Craighead 1970). It was anticipated that at the end of the summer season, some grizzlies would appear in the town limits. By mid-October only a couple of unconfirmed comments were known about the presence of a few grizzlies in the town of West Yellowstone. Reliable reports indicate the appearance of one or two on one or two occasions in West Yellowstone during October, 1970. This is a contrast to the several grizzlies being usually present in the town for a period of 6 weeks in September and October of 1969.

During 1970, growing conditions were perfectly coordinated for an outstanding production of huckleberries throughout the State. It can be considered that grizzly utilization of excessively abundant and widespread huckleberry crops satisfied and exceeded their forage requirements. This factor, along with some early snowfalls in mid-September and early October, may have influenced the distribution of many grizzlies toward a denning area rather than directing their foraging into the dump or city area.

A major action was initiated to establish a new dump site with current standards of sanitary landfill and in this case to also have an enclosed bearproof fence. When the new dump is available and in use, about 2 miles north of the present dump area, the old dump will be eliminated.

This new dump may or may not change the foraging of grizzlies in the city of West Yellowstone. Free-roaming grizzlies in close proximity to people are a potential hazard and contingent policies are to preclude a human-grizzly encounter. Such an encounter is widely publicized and may result in hasty counter measures which are usually detrimental to the species.

It appears that a program of observation, live-trapping and discriminate disposal is necessary for grizzly bears appearing in the town limits of West Yellowstone. If grizzlies are not recognized as repeated visitors they may be transferred and released at a distant site. When live traps are not effective, immobilization techniques or snare traps may be efficiently utilized. It may be necessary to remove some individuals from the population. Each mortality will provide basic data for the current studies. Hides and skeletons will be available for the several requests from museums and educational institutions for specimens.

\section{CONCLUSIONS}

Montana has the largest population of grizzly bears in the contiguous states. In the past 30 years, hunting for the species has been and continues to be unlimited to residents and non-residents. A concern for this rare carnivore has always been recognized and the Game Department is responsible for maintaining the status and welfare of the grizzly bears in Montana.

An accurate indication of the hunters' harvest of grizzlies is available from the current licensing structure. The licensing may be refined by increasing the fee for a grizzly bear hunting license, and requiring an interim period for successful hunters before qualifying for another grizzly hunting license.

Publicity and information methods will inform grizzly hunters of the deadline date for obtaining a license, and of the regulation requiring the hunter to be responsible for recovering and possessing a hide and skulls-after killing a grizzly bear. 
Providing information to personnel and other agencies about current programs does provide the necessary assistance in obtaining complete specimens, samples and valid reports of grizzly bears killed in Montana.

During some years, grizzly bears freely roam in the town of West Yellowstone and such a close proximity is an extremely potential hazard to people, agencies and the grizzlies. An explicit policy should prevail for this area to preclude such a possible event.

The examination and utilization of complete carcasses provide basic information and specimens for cooperative studies with the Veterinary Research Laboratory, Park Service and other scientific institutions. Regulations provide for the recovery, processing and return of grizzly bear heads from hunter trophies. These hunter trophies permit a close examination for features correlated with an age for each specimen. Reliable age and sex information for the mortality is required. A continuing program is necessary to maintain a documentation of the annual mortality of the grizzly bears to provide a basis for management recommendations of this rare species.

\section{REFERENCES}

CRAIGHEAD, J. J., HORNOCKER, M. G. \& CRAIGHEAD, Jr., F.C. 1969. Reproductive biology of young female grizzly bears. J.Reprod.Fevi., Suppl. 6: 447-475.

-. 1970. Personal communication.

F. C. CRAIGHEAD, Jr.\& McCUTCHEN, H.E. 1970. Age determination of grizzly bears from fourth premolar tooth sections. J.Wildl. Mgmt. 34(2): 553-563.

GREER, K. R. \& CRAIG, V. 1970. Bear Hunting in Montana. Montana Fish and Game Publ. $7 \mathrm{pp}$.

JONKEI, C.J. 1967. Black bear population studies. Montana Fish and Game Department. W-98-R-1-6. $148 \mathrm{pp.} \mathrm{(Wildlife} \mathrm{Monograph} \mathrm{in} \mathrm{press).}$

MARKS, S.A.\& ERICKSON, A.W. 1966. Age determination in the black bear. J. Wildl. Mgmt. 30(2): 389-410.

MARSHALL, P.B. 1955. Grizzly Bear Survey. Montana Fish and Game Department, P-R Job Compl. Rept., Vol. 6, No. 1, 2. Job 1-D. pp. 112-131.

MUNDY, K. R.D. \& FULLER, W.A. 1964. Age determination in the grizzly bear. J. Wildl. Mgmt. 28(4): 863-866.

STOCKSTAD, D.S. 1954. Grizzly bear investigation and re-check. Montana Fish and Game Department, P-R Job Compl, Rept. Vol. 5, No. 2. Job 7-A. pp. 223-235. 